\title{
MANAJEMEN LAYANAN PERPUSTAKAAN UNIVERSITAS PASCAUNIFIKASI PERGURUAN TINGGI DI PERPUSTAKAAN UNIVERSITAS NURUL JADID PAITON PROBOLINGGO
}

\author{
Moh. Rifa'i ${ }^{1}$, Muhammad Fahrizal Amin ${ }^{1 *}$ \\ 1 Universitas Nurul Jadid \\ 1Jl. PP Nurul Jadid, Tj. Lor, Karanganyar, Paiton, Probolinggo, Jawa Timur 67291, Indonesia \\ * Corresponding Author. Email: muhammadfahrizalamin@gmail.com
}

\begin{abstract}
Abstrak
Penelitian ini bertujuan untuk mendeskripsikan manajemen layanan perpustakaan universitas di perpustakaan Universitas Nurul Jadid Paiton Probolinggo meliputi perencanaan, pengorganisasian, pelaksanaan dan pengawasan. Jenis Penelitian ini menggunakan penelitian deskriptif dengan pendekatan kualitatif. Teknik pengumpulan data dilakukan dengan cara wawancara mendalam, observasi lapangan, dan dokumentasi. Sedangkan teknik analisis data yang diterapkan adalah model Miles dan Huberman dengan menggunakan reduksi data, penyajian data, penarikan kesimpulan dan verifikasi data. Dengan uji keabsahan data melalui kredibilitas dengan teknik triangulasi sumber. Penelitian ini berfokus pada keadaan sebenarnya yang terjadi di perpustakaan Universitas Nurul Jadid setelah unifikasi. Hasil penelitian menunjukan bahwa perpustakaan Universitas Nurul Jadid masih pada taraf perpustakaan berkembang diukur berdasarkan visi dan misinya. Perencanaan perpustakaan Universitas Nurul Jadid sudah memadai secara prosedur dan syarat pembuatan visi dan misi. Pengorganisasian masih belum berstandar perpustakaan universitas karena SDM tidak lulusan linear dan belum tersertifikasi. Pelaksanaan masih ditemukan kendala sarana prasarana. Sedangkan pengawasan belum maksimal karena tidak dilakukan sesuai prosedur yang telah ditetapkan.
\end{abstract}

Kata kunci: manajemen, layanan, perpustakaan universitas

\section{POST UNIFICATION UNIVERSITY LIBRARY SERVICES MANAGEMENT IN THE LIBRARY OF UNIVERSITY NURUL JADID PAITON PROBOLINGGO}

\begin{abstract}
This research is aimed to describe university library service management in the library of Nurul Jadid University Paiton Probolinggo included planning, organizing, actuating and controlling. This study using descriptive qualitative method. Data collection technique is using depth interview, range observatory, and documentations. Technic of data analysis is using Miles and Huberman models; data reduction, data presentation, data conclusion, and verification. From data credibility taken from triangulation data source. This study focuses on the natural setting in the library at Nurul Jadid University after unification. The result of this study indicates that library Nurul Jadid University is still in developing library level based on its vision and mission. The planning of library Nurul Jadid University is already adequate in procedural and requisite. The organization is still not standardization university library because human resources of its library are not from the linear subject and still not certification. The actuating found constraints on facilities and infrastructures. While supervision is not maximal because it is not carried out according to the prescribed procedures.
\end{abstract}

Keywords: management, service, university library

Permalink/DOI: $h$ ttp://dx.doi.org/10.21831/amp.v7i1.22881 


\section{Pendahuluan}

Dalam kehidupan manusia, pendidikan sangat erat kaitannya dengan pengetahuan. Manusia memerlukan pengetahuan untuk kelangsungan hidup bermasyarakat dan untuk bersosialisasi. Seperti yang diungkapkan oleh Sudarsana (2014, pp. 1-3), pendidikan me-rupakan suatu usaha agar manusia dapat mengembangkan potensi dirinya melalui proses pembelajaran. Proses pembelajaran harus didukung oleh sumber daya manusia yang memadai dibidangnya dan juga peranan pendidikan. Hal ini selaras dengan usaha mencerdaskan rakyat maupun generasi bangsa yang berkelanjutan, dibutuhkan peranan pendidikan yang memadai berdasarkan perkembangan zaman serta teknologi informasi.

Dewasa ini, teknologi telah mengalami kemajuan pesat, seharusnya untuk urusan pengetahuan, mudah didapat dan tanpa batasan waktu tertentu. Menurut Napitupulu, 1967), pendidikan adalah kegiatan yang dijalankan secara sengaja, teratur, dan berencana serta bertujuan untuk mengubah manusia menjadi terdidik. Berhubungan dengan hal tersebut, Sudarsana (2014, pp. 1-4), berpendapat bahwa usaha untuk meningkatkan kecerdasan bangsa adalah melalui pendidikan formal dan non formal. Oleh karenanya, diperlukan adanya sarana komunikasi informasi ilmu yang memadai berdasarkan keperluan masyarakat. Salah satu sarana tersebut adalah perpustakaan.

Menurut penelusuran Sudarsana (2014, pp. 1-5) dalam bukunya Pembinaan Minat Baca, perpustakaan asalnya dari "pustaka" yang memiliki arti buku atau kitab. Dalam bahasa Inggris disebut library, sedangkan dalam bahasa Belanda bibliotheek, Perancis menjadi bibliotheque, sedangkan Spanyol dan Portugis bibliotheca. Kalau ditelusuri, library bermula dari bahasa Latin yaitu Liber. Kemudian akar kata bibliotheeka dalah biblos yang artinya buku. Berhubungan dengan pengertian tersebut, Pamuntjak (1976, p. 1), mengemukakan bahwa perpustakaan merupakan pusat terkumpulnya berbagai informasi dan ilmu pengetahuan baik berupa buku atau rekaman lainnya yang difungsikan untuk dapat memenuhi kebutuhan masyarakat sebagai pemakai perpustakaan.

Sedangkan pendapat Lasa (2017, p. 1), perpustakaan akan berkembang secara baik dan signifikan jika dikelola oleh sumber daya keperpustakaan yang memiliki kompetensi, dengan manajemen yang profesional dan dukungan lembaga induk yang menaunginya. Menurutnya, sumberdaya manusia perpustakaan adalah unsur yang sangat penting bagi sebuah perpustakaan dibanding dengan unsur lain pembangun perpustakaan seperti bahan koleksi, sarana prasarana, pemustaka, anggaran dana, maupun teknologi informasinya. Berhubungan dengan ini, Istiana (2014, p. 7), mengemukakan perpustakaan harus memiliki upaya agar tujuan dan fungsi pelayanan perpustakaan dapat tercapai. Dengan mempersiapkan sumber daya manusianya (pustakawan) yang siap membantu pengguna perpustakaan dalam memaksimalkan pemanfaatan koleksi perpustakaan sebagai sumber informasi.

Seperti yang diungkapkan oleh Istiana (2014, pp. 18-19), salah satu untuk menjadikan perpustakaan unggul dengan mengembangkan jenis-jenis layanan perpustakaan antara lain layanan sirkulasi, layanan refrensi, layanan keanggotaan, layanan majalah dan jurnal, layanan penulusuran informasi, layanan perpustakaan keliling, layanan cetak, fotocopy dan alih media, layanan pendidikan, layanan koleksi digital, layanan audio visual, dan layanan learning common.

Sedangkan layanan perpustakaan yang memadai diperlukan manajemen perpustakaan. Menurut Lasa (2009, pp. 200201), manajemen perpustakaan merupakan segala bentuk usaha untuk pencapaian tujuan perpustakaan yang baik dengan memanfaatkan sumber daya manusia, informasi, ilmu pengetahuan, sistem, sumber dana, sarana dan prasarana dengan tetap memperhatikan fungsi, peran dan keahlian. Tentu saja tujuan dari manajemen perpustakaan adalah untuk mengoptimalkan fungsi perpustakaan sebagai sumber informasi yang dapat dimanfaatkan semaksimal 
mungkin oleh para penggunanya secara efektif dan efisien.

Manajemen perpustakaan menjadi peran penting dalam setiap perpustakaan yang memiliki nilai kompetitif dan tujuan bersama. Manajemen perpustakaan juga akan sangat diperhitungkan di dalam perpustakaan perguruan tinggi. Perpustakaan disebut sebagai jantungnya universitas karena fungsi utamanya adalah untuk menunjang proses pendidikan, tidak hanya untuk pengetahuan seperti perpustakaan umum, di universitas, perpustakaan juga sebagai sumber informasi utama untuk penelitian dan pengabdian masyarakat yang dikenal dengan Tri Dharma Perguruan Tinggi. Hal tersebut menuntut mahasiswa agar mandiri dalam mendapatkan informasi. Namun meskipun demikian pentingnya peran perpustakaan, dalam praktiknya belum semua institusi di perguruan tinggi memiliki manajemen layanan perpustakaan yang memadai untuk penggunanya.

Menurut Sutarno (2004, p. 29), membentuk perpustakaan yang memadai ternyata tidak mudah. Karena pada lembaga yang menjadi pusat, dan bertanggung jawab untuk mengembangkan dunia ilmu pengetahuan, teknologi dan rekayasa masih menghadapi keterbatasan. Menurutnya, hal yang paling pokok adalah bagaimana memulai dan meneruskan pembinaan dan pengembangan perpustakaan di perguruan tinggi, maka solusi yang tepat yang harus dilakukan perpustakaan perguruan tinggi yaitu berupaya untuk mencari strategi dan trobosan baru dengan menerapkan manajemen yang berkaitan dengan layanan perpustakaan yang efektif dan efisien agar kebutuan pemustaka dan layanan perpustakaan dapat berjalan optimal.

Berdasarkan uraian yang telah disampaikan tersebut, maka penelitian ini bertujuan untuk mendeskripsikan manajemen layanan perpustakaan meliputi perencanaan, pengorganisasian, pelaksanaan, dan pengawasan.

\section{Metode Penelitian}

Jenis Penelitian ini menggunakan penelitian deskriptif (Descrictive Research) dengan pendekatan kualitatif. Menurut Faisal (1990, p. 1), penelitian kualitatif merupakan sebuah metode penelitian yang didalamnya mencakup pendangan-pandangan filsafati mengenai disciplined inqury dan mengenai realitas object yang distudi dalam ilmu-ilmu sosial dan tingkah laku yang sifatnya teknis motodologis dalam pekerjaan penelitian. Sehingga data yang di dapat dari sumber data (informan) dapat digambarkan secara deskriptif sehingga data yang diproleh dianggap telah jenuh.

Penelitian ini dilakukan dalam jangka tiga bulan, yakni mulai bulan SeptemberDesember 2018. Perpustakaan Universitas Nurul Jadid Paiton Probolinggo sebagai objek penelitian yang merupakan perpustakaan inti dan satu-satunya perpustakaan yang dimiliki oleh Universitas Nurul Jadid.

Latar belakang perpustakaan Nurul Jadid sebelum menjadi Universitas merupakan integrasi perpustakaan dari tiga perguruan tinggi di bawah naungan Pondok Pesantren Nurul Jadid Paiton Probolinggo, yaitu Institut Agama Islam (IAINJ), Sekolah Tinggi Teknologi Nurul Jadid (STTNJ) dan Sekolah Tinggi Ilmu Kesehatan (Stikes NJ), dalam pasca perubahanya pada tahun 2017, perpustakaan tersebut memiliki koleksi sebanyak 8.114 judul atau 12.925 eksemplar. Meliputi buku teks, terbitan berkala (jurnal), laporan akhir, skripsi, tesis, disertasi, majalah, buku referensi, laporan penelitian, CD-ROM dan dokumentasi. Koleksi pada perpustakaan juga tidak hanya terbatas pada koleksi tercetak saja, namun perpustakaan juga telah melanggan e-book dan e-journal pada beberapa penerbit internasional. Sedangkan subjek penelitian adalah aktivitas manajemen layanan perpustakaan Universitas Nurul Jadid. Dalam penelitian ini, peneliti bertindak sebagai instrument (pengumpul data lapangan) dan observator.

Sumber data adalah informan yang dianggap mengetahui dalam fokus penelitian ini dan mempertanggung jawabkan kebenaranya yaitu meliputi Kepala perpusta- 
kaan dan Staf perpustakaan Universitas Nurul Jadid dan juga mahasiswa sebagai pengguna (pemustaka). Dalam memperoleh data secara holistik dan integratif serta memperoleh relevansi data dengan fokus dan tujuan mengenai manajemen layanan perpustakaan, dalam prosedur pengumpulan data penelitian ini dengan wawancara mendalam (indepth interview), observasi partisipan (participant observation) dan dokumentasi.

Dalam keabsahan data, fokus penelitian ini menggunakan uji kredibilitas (credibility) dengan menggunakan pemeriksaan keabsahan data dengan tehnik triangulasi sumber (triangulation). peneliti akan membandingkan dan mengecek balik derajat kepercayaan suatu informasi yang diperoleh melalui waktu dan alat yang berbeda dalam penelitian kualitatif. Menurut Chairunnisa (2017, p. 117), trianggulasi merupakan teknik pengumpulan data yang berbeda-beda untuk mendapatkan data dari sumber yang sama.

Sumber data yang menunjang penelitian ini, diperoleh dengan teknik pengumpulan data yang dilakukan dengan pendekatan kualitatif. Yakni meliputi wawancara mendalam, observasi lapangan, dan rancangan ini menggunakan studi banding yang berfokus pada layanan perpustakaan Universitas Nurul Jadid setelah univikasi. Penelitian ini bersifat lebih intensif dan fokus pada manajemen layanan perpustakaan Universitas Nurul Jadid setelah diunifikasi. Prosedur analisis data dalam penelitian ini dilakukan secara interaktif dan berlangsung secara terus menerus pada setiap tahapan penelitian dengan jangka waktu penelitian yang telah ditentukan hingga tuntas dan data telah sampai pada titik jenuh. Artinya, peneliti akan menghentikan pengumpulan data pada analisis data yang sudah mencapai keabsahannya, maksudnya adalah, semua informasi yang telah didapatkan dari sumber informan sudah pokok dan tidak ada informasi baru lagi mengenai hal tersebut. Hal ini sesuai dengan proses penelitian menurut Miles \& Huberman (1992, p. 109), yaitu data reduction, data display, dan conclusion drawing/veri- fication. Peneliti akan mengolah sumber data dengan memperhatikan teori fungsi manajemen Terry (1993) yaitu; perencanaan, pengorganisasian, pelaksanaan, dan pengawasan.

Peneliti juga menjajaki dan menilai kinerja manejemen layanan perpustakaan di Universitas Nurul Jadid dengan memiliki data dari kepala perpustakaan terkait dengan lokasi, koleksi, dokumentasi, data mentah lapangan dan data-data lain yang diperlukan dalam penelitian. Peneliti sudah cukup memahami latar belakang objek penelitian dengan baik. Serta melibatkan diri sebagai tindak peneliti untuk analisis data lapangan.

\section{Hasil Penelitian dan Pembahasan}

Perencanaan Layanan Perpustakaan di Perpustakaan Universitas Nurul Jadid

Perencanaan merupakan dasar pelaksanaan kegiatan, seperti yang diungkapkan oleh Lasa (2017, p. 25), perencanaan merupakan suatu proses penentuan dan penahapan kegiatan yang akan dilakukan oleh perpustakaan dalam rangka pencapaian tujuan tertentu. Kepala perpustakaan tidak akan mampu dalam melaksanakan fungsi manajemen tanpa didukung dengan perencanaan yang matang. Asrohah (2014, p. 7) berpendapat bahwa memutuskan rencana suatu kegiatan atau organisasi, supaya tidak mengabaikan visi dan misi yang telah dibuat dan ditetapkan sebelumnya. Perencanaan yang dilakukan kepala perpustakaan Universitas Nurul Jadid dalam membuat rencana program layanan perpustakaan kepada pemustaka (pengguna) juga mengacu terhadap visi-misi perpustakaan. Hal ini masih diperkuat oleh pendapat Lasa (2017, pp. 27-31), bahwa tahapan awal perencanaan adalah penetapan visi misi, tujuan, sasaran, dan strategi pencapaian tujuan. Bahkan menurutnya, jika perpustakaan ingin kearah yang lebih baik, harus memiliki visi misi yang jelas, keahlian di bidang SDM, insentif dan rencana kerja. 
Visi dan Misi perpustakaan Universitas Nurul Jadid

Dalam proses perencanaan perpustakaan Universitas Nurul Jadid, kepala perpustakaan Nurul Jadid berkordinasi dengan pimpinan universitas dalam menyusun program jangka pendek dan program jangka panjang, program jangka pendek dilaksanakan per semester dan program jangka panjang dilaksanakan per tahun sebagai tujuan utama dari layanan perpustakaan dipergunakan agar efektif dan efisien.

Adanya visi bagi perpustakaan adalah untuk memperjelas arah kembang perpustakaan dan memotivasi seluruh komponen perpustakaan untuk mengambil tindakan ke arah yang benar secara baik sampai tujuan perpustakaan tersebut benarbenar dicapai. Menurut Lasa (2017, p. 27), adanya visi yang jelas, kompetitif, berkeunggulan, dan berjangka akan membantu mengkoordinasi kegiatan SDM perpustakaannya, visi dapat mempengaruhi petugas dalam pekerjaannya. "Menjadi pusat informasi ilmiah di Kampus Universitas Nurul Jadid dan memberikan pelayanan prima berbasis teknologi informasi untuk meningkatkan daya saing di era digital pada tahun 2020" merupakan visi perpustakaan Universitas Nurul Jadid. Visi ini merupakan suatu pemikiran yang jauh dan terencana melampaui keadaan sekarang atau yang belum pernah dicapai perpustakaan Universitas Nurul Jadid. Visi ini merupakan tahap perencanaan, dikarenaka visi tersebut mampu membaca dan menjadi jembatan tujuan bagaimana rancangan pencapaian perpustakaan Universitas Nurul Jadid ke depan. Tahap perencanaan visi menurut Lasa $(2017$, p. 29$)$ adalah memperhatikan penyusunanya, yaitu meliputi:

Pertama, melibatkan seluruh elemen yang terikat dengan perpustakaan. Dengan mempelajari kalimat dari visi perpustakaan Universitas Nurul Jadid, dalam hal ini, disebutkan bahwa keterlibatan seluruh elemen yang terikat dalam perpustakaan belum sempurna mencakup seluruhnya.

Kedua, memiliki nilai kompetitif yang unggul, dan memiliki jangkauan waktu tertentu. Visi perpustakaan Universitas Nurul
Jadid dalam standar poin tersebut telah memenuhi. Dalam visi tersebut memiliki jangka waktu tertentu dalam tujuan perencanaan visi perpustakaan yaitu tahun 2020, dan juga memiliki nilai kompetitif yang unggul di dalamnya dengan penggalan kalimat "memberikan pelayanan prima berbasis teknologi informasi untuk meningkatkan daya saing di era digital"

Ketiga, sesuatu yang memang diinginkan bersama. Visi perpustakaan Universitas Nurul Jadid telah melalui pemikiran panjang dan jauh mendalam dengan mempertimbangkan tujuan dan keinginan bersama yang berdasar pada cita-cita perpustakaan Universitas Nurul Jadid.

Keempat, mudah dipahami orang lain. Visi perpustakaan Universitas Nurul Jadid menggunakan bahasa yang padat, formal, jelas dan ringkas serta lugas dan tidak bertele-tele sehingga orang lain dapat mudah menangkap maksud dalam memahaminya.

Kelima, futuristik, yaitu visi mengandung cita-cita yang akan dicapai di masa depan dalam waktu yang lama. Visi perpustakaan Universitas Nurul Jadid telah memenuhi standar futuristic dengan adanya cita-cita dan tujuan perpustakaan Universitas Nurul Jadid, serta tahun 2020 sebagai kurun waktu dalam pencapaian jangka panjang.

Keenam, menantang, yaitu visi tersebut berisi tantangan, yang dapat menumbuhkan semangat kerja keras untuk mewujudkan visi dan tujuan dalam pencapaian jangka panjang di perpustaaan Universitas Nurul Jadid secara bersama-sama.

Ketujuh, memotivasi, yaitu visi mengandung dorongan untuk melakukan aktivitas harapan dan tujuan atau perencanaan masa depan dengan kerjasama yang terarah dan terkoordinasi dalam pencapaiannya. Hasilnya ialah, visi perpustakaan Universitas Nurul Jadid telah memenuhi standar pencapaian dalam perencanaan visi jangka panjang, jangka menengah, dan jangka pendek.

Sedangkan misinya yaitu: (1) menyediakan kebutuhan koleksi yang relevan dengan kebutuhan pemustaka, (2) me- 
ngembangkan pusat repository lokal konten (deposit) yang open access, (3) menyelenggarakan pelayanan prima yang memenuhi standar pelayanan minimum, (4) mengembangkan sistem otomasi perpustakaan yang standar, (5) mengembangkan kompetensi kepustakawanan yang bersertifikasi, (6) mengembangkan total quality manajemen dalam pengelolaan perpustakaan yang terakreditasi. Menurut Nawawi (Lasa, 2009, p. 20), menyatakan bahwa misi merupakan suatu kegiatan yang akan dilaksanakan secara oprasional untuk jangka waktu panjang oleh perpustakaan dalam merealisasikan tujuan.

\section{Sasaran strategi pencapaian tujuan}

Strategi pada dasarnya adalah sebuah cara untuk mencapai tujuan dan sasaran yang dijabarkan dalam bentuk program dan kebijakan (Lasa 2017, p.31). Kebijakan yang berarti ketentuan yang dirancang oleh perpustakaan untuk menjadi pedoman pelaksanaan kerja dan pengembangannya. Sehubungan dari misi dan visi diatas, tujuan yang ingin dicapai perpustakaan Universitas Nurul Jadid yaitu; Pertama, terciptanya relevansi antara koleksi perpustakaan dengan kebutuhan pemustaka. Kedua, tersedianya semua lokal konten dalam repositori institusi. Ketiga, tercapainya pelayanan prima yang memenuhi standar pelayanan minimum. Keempat, terwujudnya standarisasi sistem otomasi perpustakaan. Kelima, tercapainya kompetensi pustakawan yang tersertifikasi. Keenam, tercapainya akreditasi perpustakaan yang memenuhi standar total quality manajemen.

Berdasarkan enam tujuan tersebut, demi mencapai tujuannya, perpustakaan Universitas Nurul Jadid menyusun enam strategi bertahap yang berbeda-beda sesuai fokus yang akan dicapainya dengan sangat mempertimbangkan total quality sehingga dalam pencapaiannya menurut rencana strategis perpustakaan dalam hal ini, sudah baik dan memadai. Pencapaian tujuan ini ditandai dengan sudah terstandarisasi ISO tahun 2016, dan terintegrasinya data mahasiswa antara pustaka dengan sistem akademik pada tahun 2019.
Sedangkan hasil dalam kategori persentase adalah $90 \%$ unit pelayanan di perpustakaan sudah mengikuti prosedur standar pelayanan minimum ,tingkat kepuasan pemustaka terhadap pelayanan adalah $80 \%$ atau memuaskan, $60 \%$ pelayanan sirkulasi dilakukan lewat fasilitas layanan mandiri, $80 \%$ jurnal yang terbit di Unuja menggunakan OJS Universitas Nurul Jadid, 90\% koleksi bahan pustaka perpustakaan sudah terintegrasi sistem otomasi, 50\% pustakawan Universitas Nurul Jadid sudah tersertifikasi pada tahun 2018, 90\% pustakawan mampu melaksanakan tugas dengan memuaskan (menurut survei), 90\% proses dalam unit kerja sudah memiliki dokumen POB. Serta $90 \%$ unit kerja sudah mengikuti prosedur POB dengan memuaskan .

Pengorganisasian Layanan Perpustakaan di Perpustakaan Universitas Nurul Jadid

Pengorganiasian merupakan proses menyeluruh dalam mengelompokkan, mengkategorikan orang-orang, alat-alat, sarana prasarana, wewenang dan tanggung jawab sehingga tercipta satu kesatuan yang dapat dengan mudah digerakkan menuju penjapaian tujuan yang telah ditentukan sebelumnya (Lasa 2017. p. 31). Menurut Sutarno (2004, p.113), ada tiga tahapan dalam pengorganisasian, yakni penentuan struktur kerja. sama, pemilihan dan penetapan staf perpustakaan yang benar sesuai dasar prinsip (the right man in the right place), dan fungsionalisasi (pembagian tugas untuk masing-masing orang dan unit satuan kerja).

Pengorganisasian layanan perpustakaan di perpustakaan Universitas Nurul Jadid, diperlukan pengorganisasian yang tepat, agar seluruh kegiatan yang ada di perpustakaan berjalan sesuai dengan tujuan awal perpustakaan. Pembagian staf dalam perpustakaan antara lain adalah kepala perpustakaan membagi tugas kepada para stafnya sesuai dengan keahlian dari masing-masing. Perpustakaan Universitas Nurul Jadid membentuk struktur organisasi yang terdiri dari penanggung jawab, pustakawan, sekretaris, bagian layanan teknis, bagian layanan umum, bagian digital library, 
dan bagian IT. Dalam hal ini pihak yang memberikan layanan ialah kepala perpustakaan dibantu oleh staff perpustakaan, dalam proses melayani seluruh komponen pelayanan perpustakaan seperti layanan sirkulasi, layanan refrensi, kepala perpustakaan memperinci dan memberi wewenang kepada staf perpustakaan dalam hal ini tercantum dalam satuan pokok tugas staf perpustakaan. Struktur organisasi perpustakaan Universitas Nurul Jadid berada di bawah tanggung jawab pimpinan universitas dan kepala perpustakaan. Kepala perpustakaan melakukan pengawasan setiap hari dan mengadakan evaluasi setiap satu bulan sekali. Penerapan satuan tugas pokok karyawan perpustakaan Universitas Nurul Jadid sudah terorganisasi dengan baik dan berjalan lancar. Namun, perpustakaan juga kekurangan staf yang memadai seperti staf kordinator bagian layanan teknis perpustakaan. Untuk pembagian tugas dalam pelayanan perpustakaan sudah memadai, tapi staf perpustakaan juga tidak semuanya lulusan pendidikan perpustakaan yang linier. Kemudian, pendanaan di perpustakaan Universitas Nurul Jadid terorganisasi dengan baik dengan kategori dapat diatasi bersama-sama.

Perpustakaan Universitas Nurul Jadid juga bekerja sama dengan setiap fakultas untuk menyediakan koleksi buku dan jurnal yang relevan dengan mata kuliah mahasiswa sesuai bidang jurusannya. Yaitu pengadaan bahan koleksi dengan mensurvei kebutuhan buku dan jurnal wajib yang digunakan pada mata kuliah setiap jurusan. Hal ini senada dengan ungkapkan oleh Soetminah (1991, p. 71). Dalam pengadaan bahan pustaka, perpustakaan menyesuaikan dengan kebutuhan para pengguna, tetapi tidak menutup kemungkinan pengadaan bahan koleksi lain yang kurang berhubungan dengan bidang yang ditekuni oleh pengguna, karena sesuai dengan fungsi perpustakaan sebagai penyedia informasi dan penyebaran. Pengadaan bahan koleksi dengan pihak fakultas dan perpustakaan luar dalam rangka menjalankan pelayanan perpustakaan, serta memfungsikan seluruh layanan perpustakaan dengan maksimal.
Perpustakaan juga memfasilitasi rak buku, dengan tatanan judul serta topik buku yang disusun terorganisasi. Namun ada beberapa indeks buku yang belum sesuai klasifikasi.

Pelaksanaan Layanan Perpustakaan di Perpustakaan Universitas Nurul Jadid

Pelaksanaan merupakan proses pelaksanaan dari suatu program yang direncanakan agar bisa dijalankan oleh seluruh pihak dalam organisasi serta proses memotivasi agar semua pihak tersebut dapat menjalankan tanggung jawabnya dengan penuh kesadaran dan produktivitas yang tinggi dalam melaksanakan program layanan perpustakaan. Hal ini pihak perpustakaan melaksanakan sesuai prosedur yang sudah di sepakati bersama dengan menggerakkan semua staf dalam menjalankan tugas yang sudah di amanahkan kepada mereka.

Dalam hal pelaksanaan kepala dan staf perpustakaan memegang peran penting sebagai pihak yang bertugas memberikan layanan kepada warga universitas. Seperti layanan sirkulasi dan layanan refrensi, hal ini telah dilaksanakan dengan baik. Dalam pelaksanaan pelayanan ini kepala perpustakaan memberikan wewenang dan tanggung jawab terhadap staf perpustakaan dalam melayani pemustaka (pengguna) mulai melayani dari peminjaman, pengembalian, bahan refrensi dan melayani pendaftaran anggota baru.

Hasil penemuan dari penelitian selanjutnya adalah bentuk keterlibatan pimpinan universitas dan kepala perpustakaan dengan melakukan suatu penggerakan SDM yakni memberikan arahan kepada staf perpustakan yang bertujuan untuk menggerakkan SDM agar memahami arti penting dalam sebuah layanan. Namun berkaitan dengan hal ini masalah yang ditemukan adalah Pustakawan belum tersertifikasi dan belum ada tenaga subjek specialis.

Penggerakan sumber daya manusia merupakan salah satu pilar yang sangat penting dalam sebuah perpustakaan, oleh sebab itu harus selalu di kembangkan sesuai dengan kebutuhan yang harus dipenuhi sebagaiamana yang dikatakan Noe (Suhae- 
min \& Arikunto, 2013, p. 260) mengatakan pengembangan sumber daya manusia di perpustakaan dapat dilakukan dengan mengikutsertakan pada pelatihan. Pelatihan adalah usaha suatu organisasi merencanakan kegiatan untuk membantu sumber daya yang terdapat dalam organisasi agar memperoleh efektifitas dalam pekerjaan mereka yang sekarang atau yang akan datang melalui pengembangan skill, knowlegde, dan behaviour.

Selain keterlibatan peran pimpinan perpustakaan dalam mengupayakan tindak kinerja dan arahan para staf perpustakaan, pelaksanaan perpustakaan juga mencakup penyediaan fasilitas. Perpustakaan Universitas Nurul Jadid memiliki luas bangunan $16 \mathrm{~m} \times 16 \mathrm{~m}$ yang terletak di lantai dua. Perpustakaan universitas ini tidak kondusif dan tidak memiliki gedung inti, perpustakaan terletak di atas fakultas Agama Islam yang tepat berada di lantai satu, di sana terdapat ruang kelas dan kantor fakultas Agama Islam. Mengenai jam buka layanan perpustakaan yaitu, setiap hari kecuali hari jum'at dengan jam buka pukul 09:00 WIB 16:00 WIB. Jenis layanan yang ada di perpustakaan Universitas Nurul Jadid ini menguatkan pendapat jenis layanan perpustakaan yang dikemukakan oleh Hartono (2016, p. 188) dan Hamiyah \& Jauhar (2015, p. 167) bahwasanya perpustakaan harus melayani pengunjung dan pengguna perpustakaan. Perpustakaan Universitas Nurul Jadid memiliki 8 jenis layanan perpustakaan yaitu, layanan sirkulasi, layanan referensi, layanan keanggotaan, layanan majalah dan jurnal, layanan foto copy, layanan repository, layanan ruang membaca dan layanan internet.

Jenis layanan yang ada di perpustakaan Universitas Nurul Jadid dalam proses tahap pengembangan, dalam hal ini dapat diketahui bahwa perpustakaan Universitas Nurul Jadid memberikan layanan yang baik kepada mahasiswa (pengguna) sesuai standar yang ada.

Dalam mendukung jenis program layanan ini, perpustakaan Universitas Nurul Jadid sudah menerapkan sistem layanan terbuka (Open Acces) dengan tujuan mem- berikan layanan kepada pemustaka (pengguna). Kepala perpustakaan Universitas Nurul Jadid mengatakan bahwa dalam memberikan layanan dengan sistem terbuka (Open Acces) agar dapat menarik minat baca mahasiswa dengan memberikan keleluasaan mahasiswa (pengguna) dalam membaca sehingga mahasiswa lebih leluasa mencari koleksi buku apa yang mereka butuhkan. Sistem Open Access bertujuan memberikan pelayanan sepenuhnya kepada pengunjungnya. Istiana (2014, p. 13) mengatakan bahwa layanan perpustakaan yang baik yaitu menggunakan sistem layanan tertentu, dengan melihat berbagai aspek pertimbangan di karenakan masing-masing sistem layanan memiliki kekurangan dan kelebihan. Istiana (2014, p. 15) berpendapat mengenai hal ini, bahwasannya pemustaka memperoleh kebebasan untuk memilih sendiri koleksi yang diinginkan, sehingga diharapkan dapat memberikan kepuasan kepada pemustaka.

Layanan ruang baca tersedia di dalam perpustakaan dengan kondisi kurang lebar dan hanya disediakan lesehan dengan luas seperempat dari lebar keseluruan dan juga layanan foto kopi berbayar, tersedianya Hotspot gratis meskipun wifi universitas, namun tidak adanya komputer OPAC yang difasilitaskan untuk pengguna perpustakaan. Rak-rak buku terbuat dari bahan kayu sehingga masih sangat berpotensi cepat rusak karena lapuk dan rayapan. Masalah lain yang ditemukan adalah interior gedung yang kurang memenuhi kebutuhan, kurangnya perawatan gedung dan tidak adanya papan nama gedung. Jumlah komputer yang belum mencukupi dan spesifikasi yang belum sesuai dengan kebutuhan, $\mathrm{Ru}-$ angan yang belum memenuhi kebutuhan pengguna (ruang diskusi, audio visual, ruang terbuka, dan ruang belajar), jaringan internet tidak stabil, suplai listrik yang tidak stabil, belum adanya peta jaringan dan tidak adanya genset/UPS. Ancaman yang kemungkinan timbul adalah Server crash, adanya hacker, serta vandalisme terhadap fasilitas pustaka. Gedung perpustkaan tersebut sangatlah kurang luas untuk sebuah perpustakaan sekelas universitas. Hal itu 
tentu saja mengurangi layanan kepada masyarakat perpustakaannya.

Pengawasan Layanan Perpustakaan di Perpustakaan Universitas Nurul Jadid

Pengawasan adalah tindakan untuk menentukan apa saja yang perlu dilakukan, apa yang tengah dikerjakan, serta adanya koreksi terhadap kesalahan yang ditimbulkan atas hasil kerja atau prosedur kerja (Lasa 2017, p. 72). Pengawasan dilakukan dengan dua cara, yaitu pengawasan korektif dan prevetif. Pengawasan korektif adalah pengawasan yang dapat dijalankan apabila hasil dari tujuan yang dicapai itu terdapat banyak variasi. Pengawasan ini dapat dilakukan pada bidang produksi, waktu, kegiatan manusia maupun keuangan. Sedangkan pengawasan preventif adalah adalah pengawasan untuk mengantisipasi adanya kendala yang muncul pada tujuan yang sudah dicapai (Mannulang, 1990, p. 176).

Hasil dari pengawasan korektif perpustakaan Nurul Jadid mulai dari pelaksanaan program transaksi hingga literasi informasi. Para pengunjung yang menggunakan fasilitas layanan perpustakaan dan yang ikut serta dalam kegiatan layanan perpustakaan untuk melakukan evaluator dan juga perlu dipantau untuk mengetahui program layanan perpustakaan ini berhasil atau tidak. Di perpustakaan Universitas Nurul Jadid evaluasi diadakan 1 tahun per semester sekali. Namun yang terjadi di lapangan proses evaluasi tidak dilakukan sesuai prosedur dan tidak sistematis.

Sedangkan hasil pengawasan preventif adalah; Pertama, pengawasan dari pimpinan universitas dalam realitanya dalam menyusun program perencanaan perpustakaan, pimpinan universitas juga dilibatkan dalam menyusun program, hal ini merupakan bentuk pengawasan pimpinan universitas terhadap perpustakaan Universitas Nurul Jadid. Pangestu (1976, p. 39) menyatakan bahwa pengawasan itu para manajer pada umumnya menganggap perlu untuk mengecek apa yang telah di lakukan, guna dapat memastikan apakah pekerjaan orang-orangnya dapat berjalan dan memuaskan. Menurut penulis pengawasan layan- an yang ada di perpustakaan Universitas Nurul Jadid menguatkan dari teori tersebut, yaitu melibatkan manajer dalam melakukan pengawasan.

Kedua, pengawasan dari kepala perpustakaan sendiri, kepala perpustakaan selalu mengawasi setiap harinya. Karena setiap hari kepala perpustakaan berada di perpustakaan. Ruangan kepala perpustakaan yang terbuka juga sangat memudahkan dalam melakukan pengawasan. Kepala perpustakaan Universitas Nurul Jadid juga menegaskan bahwa pustakawan dan bagian layanan perpustakaan sebagai evaluator pada pemustaka setiap harinya.

\section{Simpulan}

Dari hasil pembahasan penelitian di atas, peneliti menyimpulkan sebagai berikut. Pertama, Perencanaan Perpustakaan Universitas Nurul Jadid Paiton Probolinggo. Dalam tahap perencanaan visi dan misi, perpustakaan Universitas Nurul Jadid sudah memenuhi standar penyusunan visi dan misi menurut pemikiran Lasa. Visi dan misi perpustakaan Universitas Nurul Jadid sudah mewakili bentuk perencanaan pemikiran dalam pencapaian tujuan dan pelayanan perpustakaan. Misi perpustakaan Universitas Nurul Jadid yang meliputi enam poin tersebut, mengandung nilai-nilai tujuan yang harus dicapai bersama dengan disusunnya rencana sasaran strategis pencapaian tujuan perpustakaab universitas dengan sudah adanya beberapa hasil dari pencapaian tersebut dengan kategori memuaskan.

Kedua, Pengorganisasian Perpustakaan Universitas Nurul Jadid Paiton Probolinggo. Pengorganisasian SDM dan kinerja yang diterapkan di perpustakaan Universitas Nurul Jadid sudah dilaksanakan dengan baik, keterlibatan pimpinan perpustakaan dalam menerapkan pengorganisasian struktur staf dan kinerja sudah diatur dengan baik dalam penerapan satuan pokok karyawan perpustakaan Universitas Nurul Jadid. Namun menurut pemikiran Sutarno, berdasarkan hasil penelitian kurang memuaskan. Salah satunya adalah perihal bebe- 
rapa komponen SDM yang ditugaskan di perpustakaan Universitas Nurul Jadid bukan dari lulusan yang linier dan beberapa staf belum tersertifikasi dan belum adanya tenaga perpustakaan subjek spesialis.

Ketiga, Pelaksanaan Perpustakaan Uni-versitas Nurul Jadid Paiton Probolinggo. Perpustakaan Universitas Nurul Jadid memiliki 8 jenis layanan perpustakaan layanan sirkulasi, layanan refrensi, layanan keanggotaan, layanan majalah dan jurnal, layanan foto copy, layanan repository, layanan ruang membaca dan layanan internet. Layanan sirkulasi dan referensi di perpustakaan Universitas Nurul Jadid telah terlaksana dengan baik sesuai prosedur. Ada staf tersendiri untuk pelayanan peminjaman, pengembalian, bahan referensi dan penganggotaan baru. Meskipun perpustakaan Universitas Nurul Jadid sudah menerapkan layanan open acces dan hotspot gratis, namun pelaksanaan sarana dan prasarana perpustakaan Universitas Nurul Jadid masih mengalami kendala yang cukup serius. Diantaranya adalah; gedung perpustakaan yang sama sekali belum memadai dan non kondusif untuk sebuah perpustakaan inti universitas, pelayanan foto kopi yang masih berbayar, tidak tersedianya computer mandiri untuk akses OPAC bagi pengguna perpustakaan, beberapa ruangan yang belum memenuhi kebutuhan seperti adanya ruang baca yang masih lesehan, rak buku kayu yang berpotensi mudah lapuk dan tidak tahan lama, interior perpustakaan yang masih jauh dari standarisasi perpustakaan universitas, serta meskipun tersedianya akses wifi gratis, namun jaringan internet mudah tidak stabil.

Keempat, Pengawasan Perpustakaan Universitas Nurul Jadid Paiton Probolinggo. Ada dua jenis pengawasan yang diterapkan di perpustakaan Universitas Nurul Jadid. Yaitu pengawasan korektif dan pengawasan preventif. Pengawasan keduanya ini sudah diterapkan dengan baik oleh para staf yang telah diberikan wewenang dan tanggung jawab. Namun di perpustakaan Universitas Nurul Jadid meskipun pengawasan dilakukan setiap hari dan diadakannya evaluasi setiap satu bulan sekali, yang terjadi di lapangan tidak demikian. Melainkan proses evaluasi tidak dilakukan sesuai prosedur yang telah ditetapkan dan tidak berjalan sistematis.

Dari simpulan di atas, peneliti menyarankan kepada kepala perpustakaan Universitas Nurul Jadid sebagai berikut.

Pertama, meninjau lebih intensif terhadap kesiapan sarana dan prasana yang ada di perpustakaan Nurul Jadid untuk menjadikan perpustakaan inti yang berorientasi dan layak bersandarisasi perpustakaan Universitas.

Kedua, Melihat lebih teliti jika adanya peluang untuk menjadikan perpustakaan yang sekarang masih berkembang menjadi perpustakaan maju. Misalnya dengan adanya pengarahan workshop keperpustakaan, pelatihan orientasi perpustakaan, dan seminar-seminar yang berhubungan dengan pembangunan perpustakaan. Ha ini berguna untuk meningkatkan kualitas SDM perpustakaan Universitas Nurul Jadid yang notabene berlulusan tidak linear.

Ketiga, Menggagas inovasi untuk merencanakan merenovasi perpustakaan atas rekomendasi dan perizinan rektor universitas. Keempat, Mengarahkan tugas dan wewenang terhadap staf perpustakaan dengan pertanggung jawabannya setiap bulan atau setiap periode yang ditentukan dan disepakati bersama dalam bentuk laporan atau presentasi individu.

Kemudian saran untuk staf pelayanan perpustakaan Universitas Nurul Jadid adalah sebagai beriku. Pertama, meningkatkan pelayanan dan menunjang kinerja yang telah dibebankan kepada staf pelayanan perpustakaan.

Kedua, menciptakan suasana harmonis perpustakaan secara bersama-sama dan menjalankan tugas serta tanggung jawab dengan cara menyampaikan kendala dan melaporkan hasil evaluasi dalam bentuk tertulis atau presentasi secara rutin atau berkala sesuai waktu yang telah disepakati.

\section{DAFTAR PUSTAKA}

Asrohah, H. (2014). Manajemen mutu pendidikan. Surabaya: UINSA Press. 
Chairunnisa, C. (2017). Metode penelitian ilmiah aplikasi dalam pendidikan dan sosisal. Jakarta: Mitra Wacana.

Faisal, S. (1990). Penelitian kualitatif; dasardasar dan aplikasi. Malang: YA3 Malang.

Hamiyah, N., \& Jauhar, M. (2015). Pengantar manajemen pendidikan di sekolah. Jakarta: Prestasi Pustaka.

Hartono. (2016). Manajemen perpustakaan sekolah. Yogyakarta: Ar-Ruzz Media.

Istiana, P. (2014). Layanan perpustakaan. Yogyakarta: Penerbit Ombak.

Lasa. (2009). Manajemen perpustakaan. Yogyakarta: Gama Media.

Lasa. (2017). Manajemen sumber daya manusia perpustakaan. Yogyakarta: Penerbit Ombak.

Mannulang, M. (1990). Dasar-dasar manajemen. Jakarta: Ghalia Indonesia.

Miles, M. B., \& Huberman, A. M. (1992). Analisis data kualitatif: buku sumber tentang metode-metode baru. Jakarta: UI Press.
Napitupulu, W. P. (1967). Dimensi-dimensi pendidikan. Jakarta: BPK Gunung Mulia.

Pamuntjak, S. R. (1976). Pedoman penyelenggaraan perpustakaan. Jakarta: Gramedia Pustaka Utama.

Pangestu. (1976). Manajemen suatu pengantar. Jakarta: Ghalia Indonesia.

Soetminah. (1991). Perpustakaan kepustakawanan dan pustakawan. Yogyakarta: Kanisius.

Sudarsana, U. B. (2014). Pembinaan minat baca (2nd ed.). Bandung: CV Pustaka Setia.

Suhaemin, S., \& Arikunto, S. (2013). Manajemen perpustakaan di madrasah aliyah negeri Yogyakarta. Jurnal Akuntabilitas Manajemen Pendidikan, 1(2), 252-268. https://doi.org/10.21831/amp.v1i2.2 398

Sutarno. (2004). Manajemen perpustakaan. Jakarta: Samitra Media Utama.

Terry, G. R. (1993). Principles of management. Illinois: Learning System Compani. 